\title{
Application of Waste Sawdust as Mixed Polyurethane Insulation in Traditional Cold Storage of Fishing Vessel
}

\author{
Sutopo Purwono Fitri ${ }^{1}$, M. Badrus Zaman ${ }^{2}$, Dwi Priyanta ${ }^{3}$, Mochamad Hidayat ${ }^{4}$
}

\begin{abstract}
- in the process of fishing it takes some supplies such as fishing equipment, instrumentation and storage of fish. The traditional fishermen of their fishing days fishing usually only bring ice cubes. Solid plastic polyurethane foam is a mixture solution of polyols and isocyanates, commonly used as an insulating material storage. From the observation waste generated being sawmill sawdust per spindle with diameter of $30 \mathrm{~cm}$ and a length of $1 \mathrm{~m}$ with 5 times sawmill, Saws $0.8 \mathrm{~cm}$ thick produced $0.0088 \mathrm{~m}^{3}$ / burnable logs only discarded. Therefore takes thermal conductivity test to review mixture of sawdust and polyurethane comparison with variations different dosing. Maximum disposals sawdust can be done is $40 \%$ of the total volume of material mixture, polyurethane and sawdust because composite material (sawdust-polyurethane) can not be bond with good so easy slab separately from origin form. Thermal Conductivity insulating good and economical on disposals $40 \%$ wood flour $\left(0.05252 \mathrm{~W} / \mathrm{m}^{\circ} \mathrm{C}\right)$ and is able to maintain a $2 \mathrm{~kg}$ of ice crystals melt up perfect on 34 hours. Operating profits economical from $4,8 \mathrm{~m}^{3}$ insulation composite application with obtained $\mathrm{Rp} 4.486 .000$ compared with $100 \%$ Polyurethane Insulation Manufacture.
\end{abstract}

Keywords—sawdust, composites, polyurethane, insulation and thermal conductivity

\section{INTRODUCTION}

In the process of fishing It takes some supplies such as fishing gear, fishing fleets, instrumentation and storage of fish. The fisherman-old traditional fishermen of their fishing days fishing usually only bring ice blocks as differences boat handling of fish in order to fish quality when arriving at the fish landing site to keep fresh.

The quality of fish storage is highly dependent on the quality of the heat insulating material (insulator) is used. The use of insulated hatch it can save ice delivered during fishing operations. The amount of ice left on landing and the demolition was still quite a lot, which is between $20-30 \%$ and even up to $50 \%$ [8].

Polyurethane is a material used as insulation retaining the temperature in the hold fish storage. But today, the constraints are felt particularly by fishermen is the problem of insulating material costs continue to rise, this limitation due to the high price of raw materials insulation.

From sawmills, wood waste are produced in the form of sawdust and pieces of wood. From the results of field observations sawmill waste generated per logs into wood powder with diameter of $30 \mathrm{~cm}$ and a length of $1 \mathrm{~m}$ to 5 times the mills, saws $0.8 \mathrm{~cm}$ thick produced $0.0088 \mathrm{~m}^{3}$ / spindle just thrown away or burned [5]. These powders have the potential to be used as a substitute raw material insulator. With special handling will find the composition that allows for the use of sawdust as raw

Sutopo Purwono Fitri, Department of Marine Engineering, Institut Teknologi Sepuluh Nopember, Surabaya, 60111, Indonesia. Email: sutopopf@gmail.com

M. Badrus Zaman, Department of Marine Engineering, Institut Teknologi Sepuluh Nopember, Surabaya, 60111, Indonesia. Email: drus_zaman@yahoo.com

Dwi Priyanta, Department of Marine Engineering, Institut Teknologi Sepuluh Nopember, Surabaya, 60111, Indonesia. Email: priyanta@gmail.com

M. Hidayat, Department of Marine Engineering, Institut Teknologi Sepuluh Nopember, Surabaya, 60111, Indonesia. Email: - material or a mixture of an insulating material on a fishing boat hatch.

Therefore, the thermal conductivity test is required for a mixture of sawdust and polyurethane with a variety of dosage ratio of $10 \%$ to $90 \%$. With this research is expected sawdust (waste wood factory) will be used as raw materials or mixtures insulator cheaper, but still had a good insulator properties and can be made by the traditional fishermen.

\section{METHODOLOGY}

Before performing composite manufacturing steps being taken in the implementation of this research are:

\section{A. Specimen Preparation}

1. Determination comparison inflate (expand) the weight of the polyurethane mixture to form a solid foam volume by mixing a solution of polyol and isocynate (1:1) are applied to the volume manufacturing of specimen with size $250 \times 250 \times 25 \mathrm{~mm}$

2. Sawdust sifted separated from the cut pieces of wood. Drying is done with dried under the sun for a day. As well as doing specific gravity measurements.

3. Beginning with the creation of $100 \%$ polyurethane specimen in the mold $250 \times 250 \times 25 \mathrm{~mm}$. The use of a mixture of polyol and isocynate based measurement of the expansion ratio by weight solution. Then the composition of polyurethane and wood powder made by adding sawdust $10 \%, 20 \%, 30 \%, 40 \%, 50 \%, 60 \%$, $70 \%, 80 \%$, $90 \%$ on the specimens $250 \times 250 \times 25 \mathrm{~mm}$.

\section{B. Apparatus}

Thermal conductivity measurement based on ASTM C177. Tests performed on the specimen by placing the specimen on the hot and cold plates are then measured using a thermocouple on both sides of the inside of the second plate. Conductivity measurement is done by attaching a thermocouple probe on the inside of the plate and put the thermocouple probe into the center of the 
specimen sandwiched between the two plates. Recording of temperature is done in 60 minutes on each specimen.

1. Heating plate of copper with a thick 250x250x1mm size suction onto the heater. Heating plate which generates heat flux wrapped in aluminum foil to minimize heat losses while measuring.

2. The cooling plate is also of copper with a size 250x250x1mm affixed with copper pipe to drain the water so that the cooling plate can decrease the environmental temperature.

Heating plate is placed on the bottom that has been affixed to one side ditengan thermocouple probe in the plate, and next to the cooling plate on which is also attached a thermocouple probe on the inside. The specimen is clamped between the two plates of hot and cold with the meeting, all parts wrapped in aluminum foil wrapped to avoid loss of heat at the time of measurement.

\section{Coolbox}

Two crates insulated coolers (Coolbox) made of a composite material of $100 \%$ and most optimal powder with a size of $15 \times 15 \times 15 \mathrm{~cm}$ inner and $2.5 \mathrm{~cm}$ thick and coated with fiberglass on the inside and outside of $1 \mathrm{~mm}$ thick. On the inside is filled with ice crystals amounting to $2 \mathrm{~kg}$. measurements were carried out every hour for 40 hours which begins when the condition of full ice until the ice melts perfectly whole. Measurements carried out on specimens and specimen $100 \%$ polyurethanepolyurethane composite wood powder which meets the characteristics most excellent insulator material with consideration of sawdust most.

The comparative tests intended to determine the ability of the composite to the conductivity which still meets the characteristics as the insulator material on the addition of a mixture of wood flour maximum. The test is applied to the ability of composite insulators in maintaining the temperature inside the coolbox to time, the condition of the ice melted at the temperature of melting ice is perfect (total) compared with the use of polyurethane insulation capability of $100 \%$.

\section{Economic}

Comparison of economic benefit is done by comparing data obtained polyurethane material needs of field observations in the manufacture of insulation 30GT hold a fishing boat in the area Paciran, Lamongan with the use of wood-polyurethane composite powder in accordance with previous measurements performed. Observations were made to obtain data - data is as follows:

- The need for insulation in the hold space (volume)

- Price per kilogram Polyurethane A and B

- The price of waste sawdust

\section{RESULTS AND DISCUSSION}

\section{A. Specimen}

Making test specimen can only be made for the specimen number 1 (as in figure 1 ) to 5 , or at $100 \%$ PU to PU mixing $60 \%$ and $40 \%$ of wood powder. Unable to mixing of the dough when mixing because of too little amount of PU so that uneven and imperfect specimen.

Polyurethane composite specimens with $50 \%$ or by adding a mixture of sawdust $50 \%$ or smaller, polyurethane solution can not be spread evenly throughout the side and penetrated the sidelines of sawdust. So that the specimen is not perfect, easily damaged and sawdust easily detached due to lack of binder (polyurethane) as shown in Figure 2. Therefore, in this study the characteristics of thermo physical measurements can only be performed on a specimen of composite polyurethane sawdust $60 \%$ and $40 \%$.

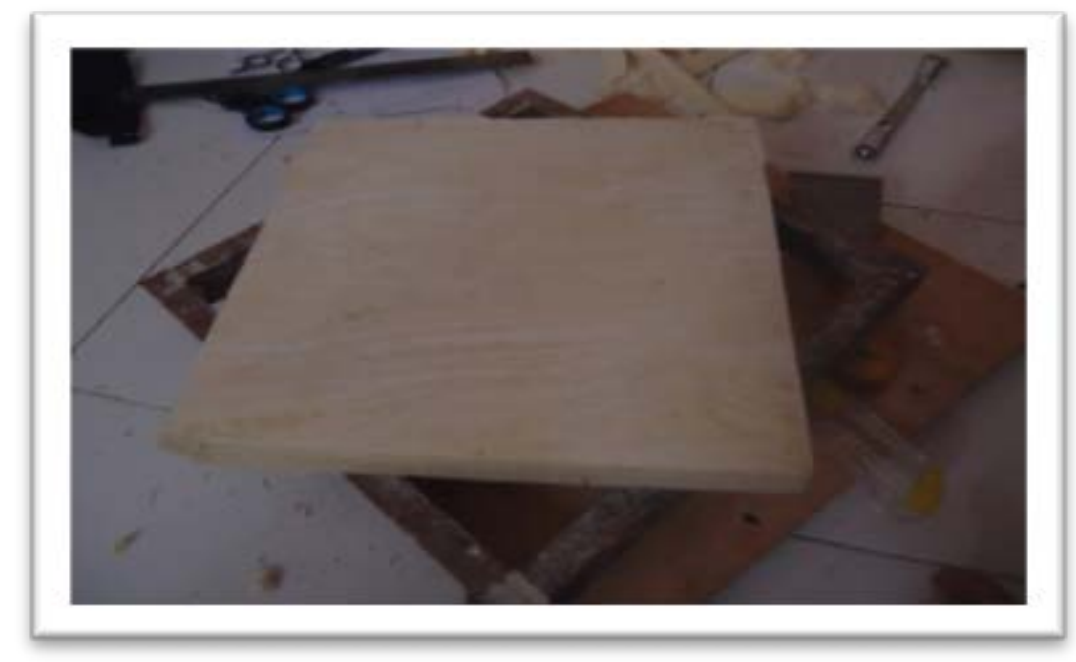

Figure. 1. Specimen $100 \%$ Polyurethane 


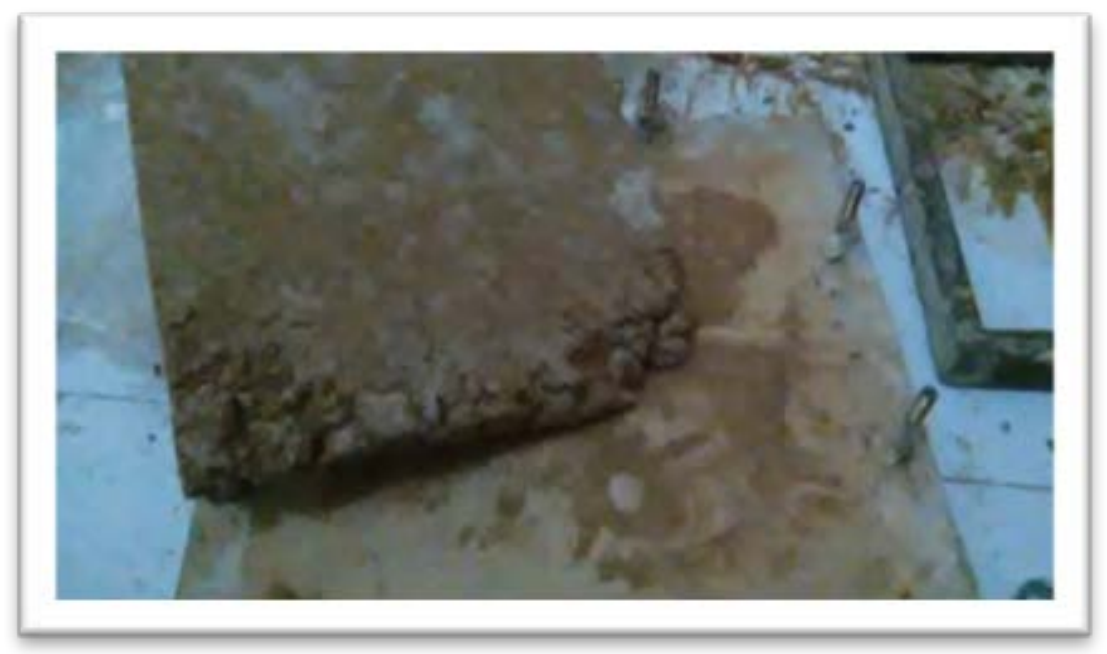

Figure. 2. Specimen Failure (50\% PU,50\%Sawdust)

\section{B. Thermal Conductivity}

Measurements of thermal conductivity in this study to determine the ability to conduct heat from the heating plate which is based on electrical current of 5.28 watts at a room temperature of $29^{\circ} \mathrm{C}$. Here are shown the results of thermal conductivity measurements on each specimen-polyurethane composite wood dust in figure 3.

Based on the measurement results as shown in figure 3 , on the fifth specimen thermal conductivity composites still qualify thermal characteristics is used as an insulator (in terms of thermal conductivity of $0.02 \mathrm{~W} / \mathrm{m}^{\circ} \mathrm{C}$ to $0.06 \mathrm{~W} / \mathrm{m}^{\circ} \mathrm{C}$ ) [8] is a specimen by mixing sawdust $10 \%, 20 \%$, $30 \%$ and $40 \%$.

\section{Coolbox}

Coolbox is made from $100 \%$ polyurethane and composite then each filled with $2 \mathrm{~kg}$ of ice crystals. Measurements were made every hour and thawing of ice every two hours for 40 hours. The measurement results as shown in the figure 4 .

The use of composite insulators $60 \%$ polyurethane and $40 \%$ wood flour lowered resistance to maintain the condition of the ice in a coolbox than using $100 \%$ polyurethane, within 34 hours of the start of the ice had melted completely. The use of composite mixture of
$40 \%$ of wood powder able to maintain a temperature below $10^{\circ} \mathrm{C}$ for 17 hours. While the use of $100 \%$ polyurethane capable of maintaining a temperature below $10^{\circ} \mathrm{C}$ for 24 hours. However, 60\% polyurethane composites can be used as an insulator in particular for vessels operating hatch one day fishing, because they can maintain the ice up to 34 hours, is sufficient for all operational needs. In addition, the composite can save up to $40 \%$ the use of polyurethane.

\section{Economic}

From the observation hatch insulation manufacturing of fishing vessels Paciran, Lamongan. It takes $420 \mathrm{~kg}$ of a mixture of PU A and PU B for insulation of $4.8 \mathrm{~m}^{3}$ at a price of Rp 32,000 per kilogram PU.

On the application of a composite mixture of $60 \%$ polyurethane and $40 \%$ sawdust, a reduction in the cost of consumption of polyurethane as much as $40 \%$, but there is an additional cost of $\mathrm{Rp} 390,000$ for the purchase of sawdust. Total cost of the need for insulation composite head is Rp 8.954 million. With the use of this composite, gain an initial investment of Rp 4.486 million.

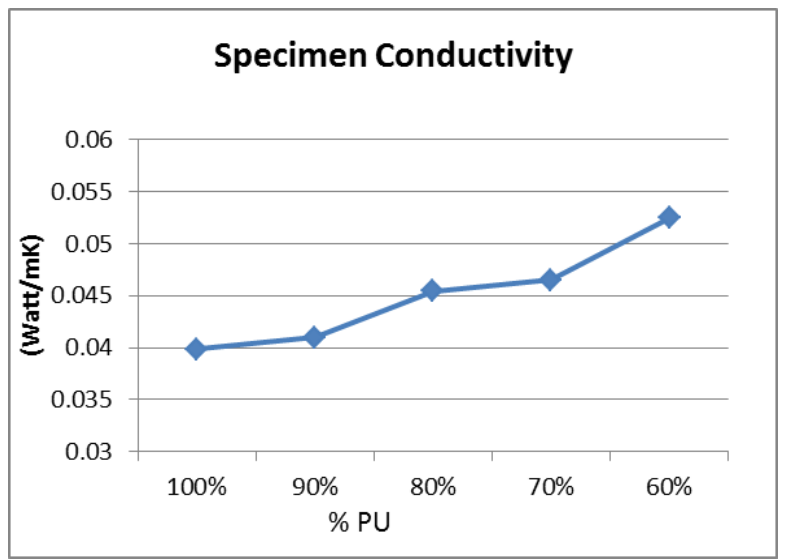

Figure. 3. Specimen Conductivity 


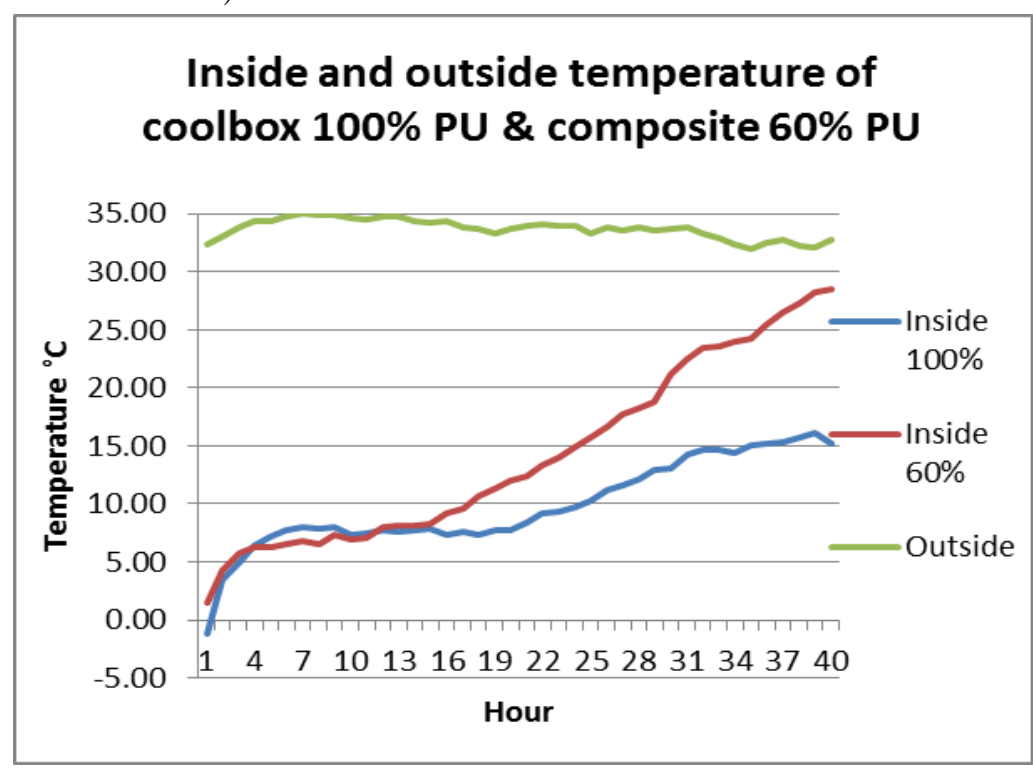

Figure. 4. Inside and outside temperature of coolbox specimen

TABLE 1.

$100 \%$ POLYURETHANE PRODUCTION

\begin{tabular}{ccccc}
\multicolumn{1}{l}{ 100\% Polyurethane } & & Rupiah \\
\hline Volume $\left(\mathrm{m}^{3}\right)$ & Weight $(\mathrm{kg})$ & Price $/ \mathrm{kg}$ & 13.440 .000 \\
\hline 4,8 & $\begin{array}{l}210 \\
(\mathrm{~A})\end{array}$ & $\begin{array}{r}210 \\
(\mathrm{~B})\end{array}$ & 32.000 & 13.440 .000
\end{tabular}

TABLE 2.

60\% POLYURETHANE; 40\% SAWDUST PRODUCTION

\begin{tabular}{cccc}
\multicolumn{1}{c}{ Composite 60\% PU dan $40 \%$ Sawdust } & & \\
\hline Item & Consump. & Price & Rp \\
\hline $\begin{array}{c}\text { Vol. 60\% PU } \\
\text { A+B }\end{array}$ & $252 \mathrm{~kg}$ & $32.000 / \mathrm{kg}$ & 8.064 .000 \\
\hline $\begin{array}{c}\text { Vol. 40\% } \\
\text { Sawdust }\end{array}$ & $576(29$ sack $)$ & $10.000 /$ sack & 390.000 \\
\hline Man power & 1 Day, 5 Worker & $100.000 /$ day & 500.000 \\
\hline & & Total & 8.954 .000
\end{tabular}

\section{CONCLUSION}

\section{A. Technical}

The addition of wood shavings to do the maximum is $40 \%$ of the total volume of mixed material, namely polyurethane and wood. The addition of wood dust is more than $40 \%$ can not be done because the composite material (sawdust-polyurethane) can not bind to either because with the least amount of liquid polyurethane which can not penetrate the sidelines of sawdust so easily separated from its original slab form. The addition of sawdust $10,20,30$, and $40 \%$ is a good thermal insulator according to standard ASTM. Good thermal insulator and economically in addition to $40 \%$ wood flour (conductivity of $0.05252 \mathrm{~W} / \mathrm{m}^{\circ} \mathrm{C}$ ).

Applications coolbox insulator-polyurethane composite wood powder able to maintain perfect ice to melt at 34 hours, faster than the $100 \%$ polyurethane applications that can sustain the ice for more than 40 hours.

\section{B. Economic}

Economic benefits in the manufacture of insulation hatch rate of $4.8 \mathrm{~m}^{3}$ with the application of a composite of $60 \% \mathrm{PU}$ and $40 \%$ wood powder obtained Rp 4.986 million compared with the manufacturing of $100 \%$ polyurethane insulation. 
[1] Amiruddin, W., Iskandar H. B. 2014. Efisiensi Perubahan Kerapatan Material Polyurethane Terhadap Laju Penetrasi Panas Pada Palka Kapal Ikan Tradisional. S1 T. Perkapalan F. Teknik UNDIP., Semarang

[2] ASTM C 177 (2004), "Standart Test Method for Steady-State Heat Flux Measurements and Thermal Transmission Properties by Means of the Guarded-Hot-Plate Apparatus”, American Society Testing and Materials, United States

[3] ASTM C 518 (1998), "Standart Test Method for Steady-State Thermal Transmission Properties by Means of the Heat Flow Meter Apparatus”, Annual Book of ASTM

[4] ASTM C 1045 (1997), "Standart Practice for Calculating Thermal Transmission Properties Under Steady-State Conditions”, Annual Book of ASTM

[5] Badrawada, I, G, Gde., Susilo, A. 2009. Pengaruh Kepadatan Papan Partikel Dari Tiga Jenis Serbuk Kayu Terhadap Nilai Konduktivitas Panasnya. Jurusan Teknik Mesin, Fakultas Teknologi Industri, Institut Sains \& Teknologi AKPRIND., Surabaya

[6] Hasibuan, R, I., Supomo, H., Soejitno. 2013. Analisis Teknis dan Ekonomis Penggunaan Komposit Serabut Kelapa dan Serbuk Pohon Kelapa sebagai Isolasi Kotak Pendingin Ikan pada Kapal Ikan, Jurnal Teknik POMITS, Vol. 2, No.1, ISSN: 2337-3539 (2301-9271).

[7] Kholis, M. N., Syofyan, I., Isnaniah. 2014. Study Use Powder As Raw Materials Manufacturing Saws Insulator Cooling Box Fish (Coolbox) Used Traditional Fisherman.

[8] Nasution, P., Fitri, S, P., Semin. 2014. Karakteristik Sabut Kelapa Sebagai Insulator Palka Ikan, Berkala Perikanan Terubuk. Hal 8292 ISSN 0126 - 4265 